\title{
Visual Representation of the Intellectuals and Philosophers in the Hungarian Reform Era (1825-1848)*
}

\author{
BÉLA MESTER \\ Institute of Philosophy, Research Centre for the Humanities, 4 Tóth Kálmán Street, 1097 Budapest, Hungary \\ Email: mester.bela@abtk.hu
}

\begin{abstract}
In the modern cultural industry, visual representation acquired a special role. In East-Central Europe, portraits made in this crucial epoch created a solid visual canon of the national classics. Another sign of this cultural transformation is the new structure of the public realms, because of the functional transformation of the usage of urban places. In the case of the topic of this paper, the Hungarian Reform Era (18251848) was this crucial epoch. In the present paper, an overview of the appearance of the portraits of the known intellectuals will be offered. In the non-censored press of the revolutionary period, the genre of caricature appeared as a counterpart of these 'star-portraits', as it will be shown in the next section. In the last section, a tension of these highly individualised portraits will be analysed both in the idealistic form of 'star-portraits' and the caricatures, and the appearance of the same figures within the visual representation of the revolutionary mass-scenes. The most emblematic location from this point of view is the place around the Hungarian National Museum. In the history of the European philosophy, this transformation of the visual representation and the usage of public realms is connected with the subsequent waves of the common sense philosophy from its Scottish roots through the philosophy to its special role in the Hungarian intellectual life.
\end{abstract}

Keywords: caricatures, Hungarian Reform Era (1825-1848), portraits, public realms, common sense, visual representation

\section{INTRODUCTION}

The theoretical starting point of the present paper is based on a new combination of four key concepts of the cultural memory. All of them have a whale of theoretical literature in the history of philosophy, and a long series of case studies that show their relevance in concrete historical and contemporary examples. Here I can touch their combination solely from the point of view of their visual appearance, by means of 19th-century examples of the Hungarian intellectual history.

* This paper was supported by the Hungarian-Lithuanian joint project entitled 'Sustainable Urban Development (SUD) Concepts - Philosophical, Sociological and Historical Analyses' carried out within the framework of a bilateral agreement of the Hungarian and Lithuanian Academies of Sciences. 
The first key word is the Gedächtnisspur (say 'trace of memory') of Jan Assmann as the central narrative, non-visual concept of his theory of the cultural memory; the second one is Pierre Nora's lieux de mémoire as a spatial and visual, concept of the historical memory. It is interesting that the English version of Nora's term, realm of memory, connects our third term, public realm, with the concept of memory. Nora's aspect can be regarded as an endeavour to narrate the history of the public realms. The fourth key concept is the creation of the authorial self of the poets, politicians and public intellectuals of the 19th-century romanaticism as it appears in visual forms and as it was preserved in the cultural memory. The theoretical novelty of the present paper is that it offers a historical analysis of the visual representation of the distinguished figures of the cultural memory as it appears in the history of the public realms and is preserved in the cultural memory. From the point of view of the history of philosophy, the present paper links the appearance of the public philosophy cultivated by public intellectuals with the above-mentioned, visualised concepts of the cultural memory, and situates the philosophical life of the discussed period in the physical and social space. The approach of the present paper is closely linked with the Hungarian researches of the lieux de mémoire in the last years (For the first synthesis of the results of the Hungarian researches in English, with the contributions of Aleida and Jan Assmann, see S. Varga et al. 2013).

\section{VISUAL REPRESENTATION AND PUBLIC REALMS IN THE EAST-CENTRAL EUROPEAN MO- DERNITY}

Under conditions of the establishment of machinery of the modern cultural industry, the visual representation of philosophers and other intellectuals as figures of the cultural life acquired a special role within a relatively short period. In the context of the East-Central European cultural nation building, portraits made in this crucial epoch created a solid visual canon of the national classics; their figures appear in the school textbooks, on the monuments and in the handbooks in the form as they were painted, or carved in these distinguished times. This phenomenon is connected with the technological possibility of the reproduction of the artworks; portraits that were the parts of cultural memories of royal dynasties and aristocratic families as individual, unreproducible paintings can find their role in the memory and identity of a modern nation just as multiplied engravings, widespread amongst the significant actors of public opinion, via the abundant offer of the periodical of this epoch. Another visual feature of this cultural transition is the changing structure of the public realms of the cities, because of the functional transformation of the usage of urban places, from the public cafés and private saloons to the fixed places of the political demonstrations and mass meetings. By my hypothesis, there is a contradiction in the relation between the pictorial schemes of the individual portraits and the perspective of the above-mentioned new public realms in its representations. Portraits of the ideal typical pictures of the heroes of political and intellectual life cannot find easily their adequate places in the representations of the public realms. In the following, a tension between the pictorial scheme of the portraits and public realms will be outlined, exemplified by the most known cases of the Hungarian cultural nation building of the modernity, with the context of the history of Hungarian philosophy in the same epoch.

In the Hungarian case, the Reform Era was an epoch of the formation of a pictorial canon of its heroes. ${ }^{1}$ The core of my pictorial examples is a representative of this period

1 Reform Era is a crucial epoch of the Hungarian intellectual history; its symbolic starting point is the establishment of the Hungarian Scholarly Society (today: Hungarian Academy of Sciences) in 1825, and it was continued with the Revolution on 15 March 1848. 
completed with several references to the prerequisites and afterlife of this visual culture. At first, an overview of the development of the publicity of portraits will be offered. At the beginning are the collection of portraits for a close élite group of the participants of the peregrinatio academica from the time of the early modernity as album amicorum. Later, several portraits appear in the public realms, in the windows of frequented shops as cultural and political symbols; in the end is the appearance of portraits of known intellectuals as the supplements of illustration in the form of engraving in the cultural periodicals as a commercial gift for the permanent subscribers. In the following, the pictorial representation of the new-type public realms will be exemplified by emblematic scenes in the city of Pest - today it is a part of Budapest on the left bank of Danube - a famous café, the square around the National Museum and the front of the most important printing house as a symbol of the dominant media of this epoch. In the non-censored press of the revolutionary period, the genre of caricature appeared as a counterpart of the above-mentioned 'star-portraits', as it will be shown in the third section, with an example from the professional production of Hungarian caricatures in the second half of the 19th century. In the last section, a tension of these highly individualised portraits will be analysed both in the idealistic form of 'star-portraits' and caricatures, and the appearance of the same figures within the visual representation of the revolutionary mass-scenes. We should realise that the appearance of the most emblematic figures in the most emblematic locations is highly problematic in the pictorial representation. Both the pictures of emblematic sceneries and emblematic figures can play their roles in the cultural memory, but pictures of the same emblematic figures in a collective action at the same emblematic places are often disbelieving, in a way; however, these figures really used these spots, and played important roles in the emblematic events that happened here.

\section{TRANSFORMATION OF THE PERSONAL VISUAL REPRESENTATION FROM THE PRIVATE TO THE PUBLIC REALM}

The first step for the transition from the dynastic and familial cultural memory of aristocrats to the publicity of the intellectual life of a modern nation can be seen in the case of a series of portraits of the significant speakers of the first Diet of the Hungarian Reform Era (18251827), ordered by an aristocrat, Comte István Széchenyi, the leader of the reform movement. ${ }^{2}$ (For a detailed analysis see Bicskei 2015; for the portrait-gallery see Bicskey 2015: 85-92). This collection was made personally for Comte István Széchenyi and offered for a close group of the important and influential supporters of the social, political and cultural reforms, as well. Genre of this series follows two models of the private life of the previous epochs; first of them is a collection of the portraits of ancestors and family members of an aristocrat dynasty, on the one hand, and the second one is a visualised form of album amicorum of the humanist scholars, on the other. This series of portraits are not representing the relatives of the owner, or his fellow-students, or spiritual brothers; this is a representation of the political sphere in a private realm, constructed by the patterns of the private cultural memory, in absence of an adequate public realm for the appearance of similar pictorial representations.

2 Comte István Széchenyi (1791-1860) was the initiator of the establishment of the Hungarian Scholarly Society of the Hungarian Diet, in his speech in the House of Lords, that was the symbolic initial milestone of the Reform Era. By the words of his contemporaries, he was 'the greatest Hungarian' (in his generation). 
The second step was when the monumental portraits painted for the saloons, or 'great hall of ancestors' in an aristocrat residence, sometimes became public attraction in frequented spots of the travellers, and in the same time appear in the windows of patriotic merchants and other businessmen as a demonstration of their political opinions. The most popular ones were the monumental portraits of Comte István Széchenyi himself and a classic of the 17th-century Hungarian literature and thinking. ${ }^{3}$ The following level of the publicity of portraits is the industrial replication of the portraits by the technology of copper graving and distributed via the periodical press. Based on the evidence of the first portraits published in periodicals, it is clear that their model is the genre of smaller oil paintings of aristocrat saloons, without colours, focussed on the gestures of the face and several symbolic elements of the garment. In this period, both the roles and visual representations of the politicians, political thinkers, writers and philosophers were mixed; their portraits more and more appear in the same public realm as the visual description of the representatives of the more and more important and institutionalised public opinion. Sometimes we can differentiate the pictures made for inland, and for international public, at least; Hungarian national references in the style of garment and concrete national symbols were almost exclusively used for the Hungarian public, only. (This feature of the visual representation has its antecedents in the early modern time, as well. E.g. Zrínyi/Zrinski's 17 th-century portraits made for the English audience represent a typical dandy of the royal court in London, in the period of the Restauration. It was unimaginable and ridiculous on the frontispieces of his books written in Hungarian.) Of course, the manners of the foreign engravers, their standards, formats and the papers used by them were different, as well.

\section{MIMEOGRAPHED PORTRAIT AS A NEW GENRE}

Regardless the different intellectual and political roles and sometimes different style of the pictures made for inland and foreign usage, the really perceptible turn in the publicity of the portraits happened by the pictorial supplements of the periodicals for their permanent subscribers as a commercial gift, in the end of the year (formally as a Christmas, or New Year gift) with a surprisingly high technological and artistic quality, on a good paper, made by the best graphic artists of their age. It is emblematic that an intellectual centre of Pest was the private saloon of a known engraver and cartographer of his age, called Karacs-Tusculanum. It was actually the shop, home and saloon of Ferenc Karacs and his wife, Éva Takáts. ${ }^{4}$ In this time the known printers, editors and book merchants did not play a similar role. In the following, this phenomenon will be exemplified by the portraits of two, highly different leaders of public opinion. The first one is a public philosopher of this epoch, who was a member of several thinking tanks for the support of the reformer politicians of his age, Gusztáv Szontagh. ${ }^{5}$

3 Miklós Zrínyi/Nikola Zrinski (1620-1664) was the 'Ban' (governor) of Croatia within the Hungarian Kingdom; a strategist of the war against the Turkish Empire, politician, thinker and writer. His literary œuvre was rediscovered and republished in the Reform Era. His younger brother, Petar Zrinski, is a classic of the Croatian literature.

4 Ferenc Karacs (1770-1838) was the best engraver and cartographer of his generation in Hungary. His wife, Éva Takács (1779-1845), was the first Hungarian female public writer, a protagonist of the women's right for the participation in the public discussions. She signed her publication by her maiden name.

Gusztáv Szontagh (1793-1858) was a public intellectual, philosopher and influential critic, a member of the Hungarian Academy of Sciences. In the politics of the Reform Era, he was a member of Széchenyi's group; in the philosophical life, he was a leader of the anti-Hegelian philosophers in Hungary. 
A primary experience of his generation was the development of the machinery of the modern cultural industry, with its advantages and disadvantages. He could become a professional public intellectual who lived after his pen, at the first time in the Hungarian intellectual history, and a significant actor of the cultural nation building. In the same time, he became a participant of the proto-capitalist machinery of the cultural industry and an element of the new bureaucracy of the institutionalised scientific life. However, the latter was in an embryonic status in Hungary in his lifetime, his generation was the first who was familiar with the system of professional CVs and personal research plans, obligatory for the members of the Hungarian Academy of Sciences, as the documents of this activity are available in the Archive of the same Academy as important sources of the Hungarian image of sciences and humanities in the first half of the 19th century. (See Szontagh 1839; the same archival unit contains professional biographies and long-term individual research plans of more than a dozen new members of the Hungarian Academy of Sciences. It seems that it was the first case in Hungary when a scientific administration systematically collected and archived the CVs and research plans of the scholars; however, there is no data about the check of the accomplishment of the promises of these research planes. Cf. Szontagh's post-revolutionary memoirs from 1850-1851, with his portrait discussed below, on its frontispiece: Szontagh 2017.)

Szontagh's whole philosophy is originate to a kind of the reflection to this new situation of the intellectuals, with its constant counterparts of the world of experiences and the man-made world, built of words, and maintained by an artificial institutionalised network. Szontagh's critique of the world purely made of words contains a hidden tension between the criticised logocentric world and the world of the 'objective reality, or that of sensual experiences'; the latter must be non-verbal and visual. It is the reason of his position as the leader of the anti-Hegelian side in the period of the Hungarian 'trial on Hegel' (in the turn of the 1830s and 1840s); it is the foundation of his opinions on the concept of scientific and historical facts in the controversy on the principles of the Hungarian historiography in the early 1850s, as well. The philosophical core of his thought was expressed in the clearest form in the so-called retrial of the Hegelian trial just before his death, in the context of the Central European philosophy what is an interesting chapter of the Continental common sense theory. The connection of the new structure of the public realms, the genre of public philosophy and the modern concept of common sense is an evidence in the contemporary philosophical historiography (for a synthesis of the political aspects of this issue, see Rosenfeld 2011). A revival of the term of sensus communis in the Continental philosophy is based on the introductory chapters of the classic work written by HansGeorg Gadamer (Gadamer 2006; for the relevance of the common sense in the German history of philosophy, see Kuehn 1987). In this Continental narrative, the latest wave of the Hungarian common sense philosophy with Szontagh in its centre represents a special case in the fields of the saved central position of the political philosophy, a proto-pragmatic philosophy of sciences, and a special glance to the lifeworld of the intellectuals under conditions of modernity.

The ambiguity toward the modern world is well mirrored by the portrait of Szontagh. By the first glance, we can see a realistically designed man with expressive face, curiosity in his eyes, and irony on his lips. It is a well-done graphic of a typical 19th-century public intellectual, a critic with an individualistic personality drawn by Miklós Barabás. ${ }^{6}$ His engraving,

6 Miklós Barabás (1810-1898) is a well-known painter of this age, especially in the field of the portraits. He was the first Hungarian painter who could live after his paintbrush in the free market, without patronage of an aristocrat. 
in its context, is a commercial gift for the subscribers of an influential periodical of this age. Thus, the autonomous person and author became an object for the commercial machinery, a consciously built modern media star. Another well-known portrait of Szontagh represents other register. It is the illustration of his necrology, at about 20 years later. The first one is a high-quality separable supplement, worthy to be framed and hanged on the wall in a private saloon or in an intellectual café. The second one is a cheap replica of the first one, made by a less-skilled graphic artist, supported by easier technology and a paper of an inferior quality. Garment is simpler, face is elder, but the similarity is conspicuous. The difference of the qualities is based on the different ends of the periodicals. The first one was the forum of the educated middle class in the 1830s and 1840s, and the graphic art supplement was a commercial, communicational and visual innovation in this time. The second one was a relatively cheap weekly periodical for Sundays, for the lower classes, established in the 1850s, and its explicit aim was the transmission of a previously established visual culture for an extended audience; artistic and technological quality was just the second preference.

\section{PUBLIC REALMS OF THE 19TH-CENTURY CITY OF PEST AND THE VISUAL REPRESENTA- TION OF THE AGENTS OF THE HISTORY}

The next example is a representative of a younger generation, a much more famous person with an abundant tradition of his pictorial representation, namely the poet, Sándor Petöfi. ${ }^{7}$ However, we have his authentic portrait made by the hi-tech of his age, a daguerreotype, as well, and he has a lot of emblematic pictorial representations, his personal opinions about the new trend of the public portraits were highly pejorative. He called it a new idolatry and expressed his aims with a Platonic metaphor; by him, his spiritual face should be engraved in the souls of his audience, instead of his reproduced portraits were estimated in albums of celebrities. We should consider that the majority of his portraits was made posthumously, and the aim of the single daguerreotype was initially private, just an interesting experience about the technological novelties, offered by one of his friends. His case is an almost unique opportunity to observe how an authentic, realistic, technically supported picture can be transformed into different idealised visual representations, with variations for inland and foreign usage. In Petoffi's case, we can realise the problem of the visualisation of these idealised figures in collective actions like a revolution in $1848 .{ }^{8}$ However, Petöfi really was a central figure of the revolution, and the key events of the 'first day of the national liberty' with his participation have an important role in the national cultural memory, we have not any emblematic visual representation of his acting, or, what is we have, they are unreliable from several aspects.

For the understanding of this problem, at first we can overview the most important new-type public realms of Pest in the revolutionary days. Our first example is the square in the front of the National Museum. In this time the building of the Museum was relatively

7 Sándor Petőfi (1823-1849) was a poet, an emblematic figure of the Hungarian romanticism. He played a key role in the political life as an initiator of the revolution of 1848 . He died in the battle field in the war of independence, in 1849, as an officer of the Hungarian Army.

8 Hungarian revolution in 1848 was a typical part of the revolutionary wave of the Continental Europe, in the same year. A speciality of the Hungarian case was the long war of independence, as a consequence of the revolution, against the Austrian and Russian troops, till the autumn of 1949. 
new, it was always planned in the centre of a would-be Museum-garden, which was not established yet. Telling the truth, it happened accidentally that in the time of the revolution there was the biggest square of the city here, optimal for the mass demonstrations. Later, in the last third of the 19th century, the political usage of this location became amorphous in a way, with the establishment of the Museum garden. There were continuous demonstrations in front of the neighbouring building of the Parliament (today it is the Italian Cultural Institute), but they have not an adequate location, because the former square became a garden, as it was always planned. A novel published just before the move of the Houses of the Parliament well describes the dysfunctionality of this square, for the mass-politics (Hungarian Parliament moved to the yet uncompleted new building on the bank of the Danube, in 1902; the novel was published in 1901). A scene of the novel describes the arrangements of a demonstration: 'The serious building of the Museum is swimming in a fog, and from the fog appears a veteran $\langle\ldots\rangle$ who provides the Museum garden. $\langle\ldots\rangle$ He read $\langle\ldots\rangle$ in his morning newspaper that $<\ldots\rangle$ it is planned a demonstration in the front of the Parliament. $<\ldots\rangle$ Why? The veteran did not know it and he was not interested in it. $\langle\ldots\rangle$ He is worry just about the garden where the crowd will be cooped up by the police' (Krúdy 1960: 106-107). ${ }^{9}$

An emblematic picture describes Petöfi's legendary speech in the Museum square; legendary, because actually he did not speak here, this day. It is focussed on the mass, on the ordinary people as the actor of the history, its leader is just a point on the horizon. Another emblematic visual representation of the revolution is the distribution of the first products of the free press, after the symbolic occupation of the Landerer \& Heckenast Co., the biggest printing house of Pest in this time. We know today that people read Petöfi's poem on the distributed flyers, in small groups throughout in the street before the printing house, but the author is not present, the distributor of the flyers is an unknown activist. It is a merely typographic vision of a free nation connected via the free press, without heroes, or charismatic leaders. Another example for the public places is the emblematic café called Pilvax, a headquarter of the revolution of 1848 . We should not imagine an intimate location for rendezvous and other private affairs, it is a great café-hall, an important catalyser of the political and cultural activity, with complete editorial boards of the new-established periodicals; amongst them the so-called 'table of the public opinion', the usual place of Petoffi's group, 'the tens'. The café-hall is full of anonym figures; portraits on the wall are unidentified, as well. However, Petöfi was an everyday guest in here, and his post address was in this time just 'at the Pilvax in the city of Pest', he is absent from the known pictorial representation of his favourite café.

\section{A SPECIAL VISUALISATION OF THE AGENTS OF POLITICS: THE EMERGENCE OF THE GENRE OF CARICATURE}

Surprisingly, the most characteristic visualisations of the well-known, emblematic figures appear in their caricatures, as a consequence of the free press and free political activity of the revolution. We can see that in the realistic graphics of the emblematic sceneries, the figures are usually anonymous representatives of the people, of the nation. The artists of the realistic, idealised, sometimes emblematic portraits of the well-known figures of the cultural,

9 Gyula Krúdy (1878-1933) is a well-known Hungarian writer, novelist. He is known as a chronicler of the milieu of the ancient Buda and Pest. The work quoted here is his first novel. 
intellectual and political life see their models from a highly individualistic, personal point of view. In realistic graphics of this period about the cafés of Pest we can often see meetings of anonymous members of an editorial board of an unknown periodical; they seemingly have a serious discussion. The pictures where we can see concrete, actual editorial boards, amongst them that of the radical newspaper of Petoffi and his circle, are usually caricatures. The best-known caricature of Petoffi's circle in the revolutionary time touches both the habits and characters of the visualised people, and the vanity of their aims, from the point of view of the graphic artist; we can see actually that they are editing a newspaper without manuscripts and writing materials.

\section{CONCLUDING REMARKS}

Instead of a conclusion, we can observe that there is a tension between the canonised visualisation of the important individual figures and the visualisation of the collective social activity. It is not a speciality of the first half of the 19th century. From the second half of the century we can show representative twin-examples for the photograph of a well-known politician, and his caricature tailored by the model of the same representative photograph. Our last example is the visual representation of a politician of the last decades of the 19th century and the first years of the next century, János Asbóth. ${ }^{10}$ A well-known photograph shows an estimated, but unmovable man who becomes ridiculous in his first public action, the publication of his political program as a member of the Parliament, in his caricature on the frontispiece of a satirical-political periodical. (See Anonymous 1874. In the same issue of this periodical see his satirical intellectual portrait: B. J. 1874. The English form of his name, Sir John Asboth, in the Hungarian text refers ironically to his 'anglomania'. For a parody of his political programme, see Asbóth 1874.) Generally speaking, it seems that the canon of the visual representation, established in the 19th century, could not express its heroes as acting people in a serious form. A political agent can be acting, but ridiculous, or serious, but unmovable; but there are highly rare examples for acting and serious figures in the visual representation, in the Hungarian case.

Received 17 September 2021

Accepted 18 January 2022

\section{References}

1. Anonimous. 1874. 'A. J. legujabb frizurája (J. A.s Newest Coiffure)', Borsszem Jankó 7(364): 1.

2. Asbóth, J. 1874. 'Magyar Conservativ Politika (Hungarian Conservative Politics)', Borsszem Jankó 7(364): 8-9.

3. Bicskei, É. 2015. 'Férfi-kép. Az 1825-1827-es Országgyülés Reformereiről Egy Portrégaléria Kapcsán (The Image of Men. On the Reformers of the Diet in 1925-1827 by the Opportunity of a Portrait-Gallery)', in Identitások és médiák. Vol. I. Identitások és Váltások, ed. K. Neumer. Budapest: MTA Bőlcsészettudományi Kutatókőzpont, Filozófiai Intézet - Gondolat Kiadó, 22-92. Available at: http://real.mtak.hu/34447/1/ Neumer_javitott3.pdf (accessed 15.09.2021).

4. B. J. 1874. 'Sir John Asboth', Borsszem Jankó 7(364): 2.

5. Gadamer, H. G. 2006. Truth and Method. 2nd revised ed. Trans. W. Glen-Doepel. New York: Continuum.

6. Krúdy, Gy. 1960. 'Az aranybánya (The Goldmine)', in Az Aranybánya, Régi Szélkakasok Között, Palotai Álmok, ed. Gy. Krúdy. Budapest: Magvető Könyvkiadó, 5-373.

${ }^{10}$ János Asbóth (1845-1911) was a Hungarian novelist, political theorist and politician. As a scholar, he was known as the author of a geographical and ethnographical description of Bosna and Herzegovina. As a politician, he was known as a symbol of surprising zigzags from the radical liberal republicanism till the monarchist conservatism. 
7. Kuehn, M. 1987. Scottish Common Sense in Germany, 1768-1800. A Contribution to the History of Critical Philosophy. Foreword by L. White Beck. Kington, Montreal: McGill - Queen's University Press.

8. Rosenfeld, S. 2011. Common Sense: A Political History. Cambridge/MA, London: Harvard University Press.

9. Szontagh, G. 1839. Életírási adatok (Biographical Data). Autograph Manuscript. Archive of the Library of the Hungarian Academy of Sciences, Department of Manuscripts; Archival Reference Code: Történl. 2r $11 / \mathrm{b}$.

10. Szontagh, G. 2017. Emlékezések életemből (Memoirs from My Life). Ed. B. Mester. Budapest: MTA Bőlcsészettudományi Kutatókőzpont, Filozófiai Intézet - Gondolat Kiadó. Available at: http://real.mtak. hu/71204/ (accessed 15.09.2021).

11. Varga, P. S.; Katschtaler, K.; Morse, D. E.; Takács, M. (eds.). 2013. The Theoretical Foundations of Hungarian 'Lieux de Mémoire'Studies. Debrecen: Debrecen University Press.

\title{
Vengrijos reformų eros (1825-1848) intelektualų ir filosofų vizualinė reprezentacija
}

\begin{abstract}
Santrauka
Šiuolaikinejje kultūros industrijoje vizualinis reprezentavimas igijo ypatingą vaidmenị. Rytų ir Vidurio Europoje portretai, sukurti XIX a. pirmoje puseje, įtvirtino klasikini vaizdavimo kanoną. Kitas šios kultūrinès transformacijos požymis - nauja viešumos struktūra dèl funkcinès urbanistinių vietovių transformacijos. Straipsnyje nagrinèjama Vengrijos reformų era (1825-1848), apžvelgiami žinomų intelektualų portretai. Revoliucinio laikotarpio necenzūruotoje spaudoje karikatūros žanras pasirodè kaip „žvaigždžių portretų“ atitikmuo. Analizuojama šių itin individualizuotų portretų keliama ịtampa tiek idealistine „žvaigždžių portretų“, tiek karikatūrų forma ir pačių figūrų atsiradimas revoliucinių masinių scenų vizualiame fone. Šiuo požiūriu išskirtinè vieta yra šalia Vengrijos nacionalinio muziejaus. Europos filosofijos istorijoje ši vizualinio reprezentavimo ir viešumos transformacija yra susijusi su vèlesnemis sveiko proto filosofijos bangomis - nuo škotiškų ištakų iki Vengrijos intelektualinio gyvenimo.
\end{abstract}

Raktažodžiai: karikatūros, Vengrijos reformų era (1825-1848), portretai, viešuma, sveikas protas, vizualinè reprezentacija 